\title{
架橋斉/無機層状複水酸化物複合体の合成と ゴム架橋特性
}

\author{
平原 英俊*1・會澤 純雄*1・高橋 \\ 秋葉 洋一 $* 2$ ・成田
諭 $* 1 \cdot$ 櫻庭 英樹 $* 2$
榮一 $* 1 \cdot$ 森 邦夫*2

\section{Intercalation of Triazinethiol Molecules into Layered Double Hydroxide and Their Crosslinking Property for Halogenated Rubber}

Hidetoshi HIRAHARA ${ }^{* 1}$, Sumio AISAWA ${ }^{* 1}$, Satoshi TAKAHASHI ${ }^{* 1}$, Hideki SAKURABA ${ }^{* 2}$, Yoichi AKIBA ${ }^{* 2}$, Eiichi NARITA ${ }^{* 1}$ and Kunio MORI ${ }^{* 2},\left({ }^{* 1}\right.$ Department of Frontier Materials and Function Engineering, Graduate School of Engineering, ${ }^{* 2}$ Department of Chemical Engineering, Iwate University, 4-3-5 Ueda, Morioka, Iwate 020-8551, Japan)

Intercalation products of crosslinking agents such as 6-R-1,3,5-triazine-2,4-dithiol monoanion ( $\mathrm{R}$ is a substituent) into $\mathrm{Mg}$-Al layered double hydroxide (RTD/LDH) have been synthesized with the calcination-rehydration reaction using $\mathrm{Mg}$ - $\mathrm{Al}$ oxide precursors calcined at $500{ }^{\circ} \mathrm{C}$ for $2 \mathrm{~h}$. RTD/LDH has been modified by anionic surface active agent (AS/RTD/LDH). These organic-inorganic nanohybrids have been characterized by X-ray diffraction (XRD) and Fourier transform infrared (FT-IR) spectroscopy.. Vulcanization reaction of chlorinated acrylic rubber by AS/RTD/LDH has been investigated for the scorch time, the apparent cure rate constant and the induction period by a swing die rheometer at $170{ }^{\circ} \mathrm{C}$. The basel spacing (003) was found to be $0.83 \mathrm{~nm}$ for the intercalated product of 1,3,5-triazine2,4,6-trithiol monoanion (TT/LDH) and $0.81 \mathrm{~nm}$ for that of 6-dibutyl-1,3,5-triazine-2,4-dithiol monoanion (DB/LDH), $0.78 \mathrm{~nm}$ for the carbonate anion-intercalated $\mathrm{LDH}$ by XRD. The absorption peaks due to triazine ring $\left(1580 \mathrm{~cm}^{-1}\right)$ and methylene $\left(2950 \mathrm{~cm}^{-1}\right)$ were shown in the FT-IR spectrum of the TT/LDH and DB/LDH. These results indicate that TT or DB was intercalated into the $\mathrm{LDH}$. The AS/RTD/LDH has shown the diffraction peak similar to the RTD/LDH. The induction period $\left(t_{10}\right)$ was $0.7-1$ min using 1,3,5-triazine-2,4,6-trithiol monosodium salt, in contrast to 10 min using AS/TT/LDH. The crosslinking of chlorinated acrylic rubber using the AS/TT/LDH showed a proper induction period.

(Received on September 30, 2005)

(Accepted on February 14, 2006)

Key Words : Triazine thiol, Layered double hydroxide, Nanohybrid, Chlorinated acrylic rubber, Scorch time, Curing, Induction period

\section{1. 緒袞}

含ハロゲンゴムの架橋は，架橋点となるハロゲンの引抜 反応を経由して進行するものと考えられている。トリアジ ンジチオール化合物は，含ハロゲンゴムの架橋鼡として知 られている1,2). 含八ロゲンゴムにトリアジンジチオール を配合した架橋性組成物は, 機械的強度, 耐熱性, 耐溶剤 性そして非抽出性等に優れたゴム材料として各種産業で使 用されている.しかしながら，トリアジンジチオール化合 物は架橋反応の反応性が非常に高く，貯蔵中や加工作業中 に架橋反応が急激に進行する現象，いわゆるスコーチが生 じ易いという問題があり，貯蔵安定性や加工安定性につい

\footnotetext{
*1岩手大学大学院工学研究科フロンティア材料機能工学専攻

（テ 020-8551 盛岡市上田 4-3-5)

*2岩手大学工学部応用化学科 ( T 020-8551 盛岡市上田 4-3-5)
}

て改善が求められている，一方，電荷の異なる 2 種類以上 の金属イオンからなる層状複水酸化物 (Layered Double Hydroxides: $\mathrm{LDH})$ は一般に $\left[\mathrm{M}^{2+}{ }_{1-\mathrm{x}} \mathrm{M}^{3+}{ }_{\mathrm{x}}\right]\left[\left(\mathrm{A}^{\mathrm{n}-}\right)_{\mathrm{x} / \mathrm{n}} \cdot \mathrm{yH}_{2} \mathrm{O}\right]$ と表わされ，2 価金属イオン $\left(\mathrm{M}^{2+}\right)$ に 3 価金属イオン $\left(\mathrm{M}^{3+}\right)$ を固溶させた陰イオン性粘土化合物である. そして, マグ ネシウムとアルミニウムの層状構造化合物である組成式 $\mathrm{Mg}_{6} \mathrm{Al}_{2}(\mathrm{OH})_{16} \mathrm{CO}_{3} \cdot 4 \mathrm{H}_{2} \mathrm{O}$ で表わされるハイドロタルサイ 卜は医薬用の制酸剤 3,4$)$ ，プラスチックの受酸剤5,6) とし て利用され，FULLERらは，耐熱性で耐水性の特徴を有 するクロロスルホン化ポリエチレンゴムコンパウンドを得 るために，ハイドロタルサイトを鉛含有化合物の代替受酸 郕として用いたことを報告している7 ${ }^{7)} \mathrm{LDH}$ の性質とし て, 加熱処理して得られる熱分解物は水溶液中の陰イオン と水分子を層間に取り込み, $\mathrm{LDH}$ 構造を再構築すること が知られている ${ }^{8-10)}$ 。この反応を利用して，金属イオンや 
各種陰イオンの組み合わせで合成した LDH の環境污染物 質の除去剤11-13) や紫外線吸収剂 ${ }^{14)}$ としての研究, アミ) 酸15,16) や糖 ${ }^{17)}$ などの陰イオン化合物をゲスト物質として 取り込む研究が報告されている，LDHとポリマー系ハイ ブリッドにおいては, 中間層にポリマーなどの有機陰イオ ンを取り込んだ有機ポリビニルアルコール/LDH 複合 体 ${ }^{18)}$, ポリ(エチレンオキシド)/LDHナノ複合電解質 ${ }^{19}$, ポリアクリル酸/LDH 複合体 ${ }^{20)}$ などの研究が行われてい る。しかしながら，LDHの層間に架橋剤を導入して有機 無機ハイブリッド架橋剤として利用した研究はほとんど報 告されていない.

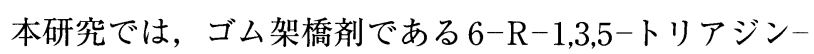
2,4-ジチオールモノナトリウム塩 (Rは置換基, RTDN)を 用いて, $\mathrm{Mg}^{2+}$ イオンに $\mathrm{Al}^{3+}$ イオンを固溶させた層状複水

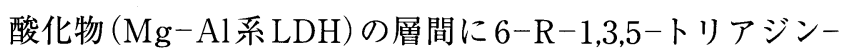
2,4-ジチオールモノアニオン (RTD)を取り込み, さらにこ れを陰イオン界面活性剂 (AS) で処理することによって架 橋剂複合型層状水酸化物を合成した。この複合体を架橋郕 として用いて塩素化アクリルゴムの架橋反応に及ぼす耐ス コーチ性について検討した。

\section{2. 実}

\section{験}

\section{1 架橋剤複合型層状水酸化物の調製}

$\mathrm{Mg}-\mathrm{Al}$ 系 $\mathrm{LDH}$ は, $\mathrm{Al} /(\mathrm{Mg}+\mathrm{Al})$ モル比 $(M R)$ の異なる 協和化学工業侏製 $\left[\mathrm{Mg}_{0.75} \mathrm{Al}_{0.25}(\mathrm{OH})_{2}\right]\left[\left(\mathrm{CO}_{3}\right)_{0.16} \cdot 0.49 \mathrm{H}_{2} \mathrm{O}\right]$ $(M R=0.25)$ (合成ハイドロタルサイト)と, $\mathrm{LDH}$ の層間に 炭酸イオンを取り込んだ $\left[\mathrm{Mg}_{0.68} \mathrm{Al}_{0.32}(\mathrm{OH})_{2}\right]\left[\left(\mathrm{CO}_{3}\right)_{0.15}\right.$. $\left.0.50 \mathrm{H}_{2} \mathrm{O}\right](M R=0.32)$ (炭酸型 $\mathrm{Mg}-\mathrm{Al}$ 系 $\left.\mathrm{LDH}\right)$ を合成したも のを使用した，炭酸型 Mg-Al系 LDH の合成のために, 1 $\mathrm{mol} / \mathrm{dm}^{3} \mathrm{Na}_{2} \mathrm{CO}_{3}$ 水溶液 $350 \mathrm{~cm}^{3}$ を $\mathrm{HCl}$ 水溶液で $\mathrm{pH}=10$ に 調整し, $40{ }^{\circ} \mathrm{C}$ で $1 \mathrm{~mol} / \mathrm{dm}^{3} \mathrm{MgCl}_{2}$ 水溶液 $400 \mathrm{~cm}^{3}$ と 1 $\mathrm{mol} / \mathrm{dm}^{3} \mathrm{AlCl}_{3}$ 水溶液 $200 \mathrm{~cm}^{3}$ の混合物を滴下し, 1 時間 かく挥, 24 時間静置, 水洗後 $1 \mathrm{~mol} / \mathrm{dm}^{3} \mathrm{Na}_{2} \mathrm{CO}_{3}$ 水溶液 $350 \mathrm{~cm}^{3}$ を加え 5 時間還流した. 固体生成物は遠心分離と 水洗を繰り返し， $40{ }^{\circ} \mathrm{C} て ゙ 24$ 時間減圧乾燥した. RTDN と しては1,3,5-トリアジン-2,4,6-トリチオールモノナトリウ ム塩 (TTN) と6-ジブチルアミノ-1,3,5-トリアジン-2,4-ジ チオールモノナトリウム塩 $(\mathrm{DBN})$ を用いた. TTNとDBN は三協化成侏製のサンチオール N1とZisnetDBNをエタノ ールで再結晶して使用した．RTDを取り込んだ $\mathrm{Mg}-\mathrm{Al}$ 系 $\mathrm{LDH}$ 複合体 (RTD/LDH 複合体) は熱分解一再水和反応 (再 構築法)により, $1 \mathrm{~mol} / \mathrm{dm}^{3} \mathrm{RTDN}$ 水溶液 $500 \mathrm{~cm}^{3}$ に 500 ${ }^{\circ} \mathrm{C}$ で2 時間焼成した合成ハイドロタルサイトまたは炭酸型 $\mathrm{Mg}-\mathrm{Al}$ 系 $\mathrm{LDH}$ の熱分解物を $2 \mathrm{~g}$ 添加し, 窒素䨌囲気中, $25{ }^{\circ} \mathrm{C}$ で所定時間振とう, 遠心分離と水洗後 $60{ }^{\circ} \mathrm{C}$ で 24 時 間減圧乾燥して合成した.ゴム架橋剂となる ASによって 表面被覆された架橋剤複合型層状水酸化物
(AS/RTD/LDH 複合体) は，RTD/LDH 複合体 $4 \mathrm{~g}$ を 20 $\mathrm{mmol} / \mathrm{dm}^{3} \mathrm{AS}$ 水溶液 $500 \mathrm{~cm}^{3}$ に添加し, 窒素雲囲気中, $25{ }^{\circ} \mathrm{C}$ で 4 時間振とうし, $40{ }^{\circ} \mathrm{C} て ゙ 24$ 時間減圧乾燥するこ とによって合成したＡS としては関東化学侏製ドデシル ベンゼンスルホン酸ナトリウム (DBS) とドデシルスルホ ン酸ナトリウム (DS) を使用した， RTDの取り込み量は振 とう前後の水溶液中 RTD濃度を島津製作所侏製全有機炭 素計 TOC500型(TOC)よって求めた. AS吸着量は, 処理 前後の溶液濃度を吸光光度法によって測定して求めた.

\subsection{RTD/LDHのイオン交換}

$\mathrm{RTD} / \mathrm{LDH}$ 複合体からの RTD放出は $\mathrm{Cl}^{-}$イオンとの交換 反応によって決定した. $100 \mathrm{mmol} / \mathrm{dm}^{3} \mathrm{NaCl}$ 水溶液 50 $\mathrm{cm}^{3}$ にRTD/LDHを $0.4 \mathrm{~g}$ 添加し, 窒素雾囲気, $25{ }^{\circ} \mathrm{C}$ で所 定時間振とう, 万過後, 万液はTOCによってRTD濃度を 測定し, RTD放出量とした.

\section{3 固体生成物の分析}

固体生成物は理学電気(侏)製 2013A 型粉末 X 線回折装置 (XRD) を使用し, 対陰極 $\mathrm{Cu}, \mathrm{Ni}$ フィルター, 管球電圧 35 $\mathrm{kV}$, 電流 $10 \mathrm{~mA}$ で測定した. フーリエ変換赤外分光光度 計 (FT-IR) は日本分光侏)製 WA-IR-7300型を使用した.

\section{4 ゴムの架橋}

含ハロゲンゴムとして日本ゼオン侏製の塩素化アクリル ゴム (AR72LS)を用い, 所定量のFEFカーボンブラック を配合し, 加硫促進剤はジブチルカルバミン酸亜鉛 (ZnBDC)，酸化防止剤はジアリール- - -フェニレンジア ミン（D P ）を使用した。架橋剤として合成した $\mathrm{AS} / \mathrm{RTD} / \mathrm{LDH}$ 複合体を所定量配合し2インチロールで混 練りした．架橋ゴムの架橋曲線は所定の架橋温度で島津製 作所侏製オシレイティングレオメーターSDR20型によっ て測定した. 耐スコーチ特性は架橋速度定数から評価し, 架橋速度定数 $(k)$ は未架橋ゴム組成物の調製 1 時間常温放 置後の試料について測定した架橋曲線から式(1)を用いて 算出した. $f_{\max }, f_{\min }$ は, 架橋曲線における最大トルク値, 最小トルク值を表し， $f_{20}$ は20分後のトルク值を表す.

$$
k=-\ln \frac{\left(f_{\max }-f_{20}\right)}{\left(f_{\max }-f_{\min }\right)}
$$

\section{3. 結果および考察}

\subsection{AS/RTD/LDH複合体}

層状複水酸化物は加熱分解すると酸化物固溶体となり, 層間に取り込んだ陰イオンと水分を放出する．この酸化物 固溶体は，陰イオン水溶液に添加することによって再び層 状構造を形成しながら, 水溶液中の各種陰イオンを取り込 む性質を持っている.この熱分解-再水和反応 (再構築法) を利用して，層状複水酸化物の層間に含ハロゲンゴムの架 橋剤として使用される 1,3,5-トリアジン-2,4,6-トリチオー ルモノアニオン $(\mathrm{TT})$ と 6-ジブチルアミノ-1,3,5-トリアジ 


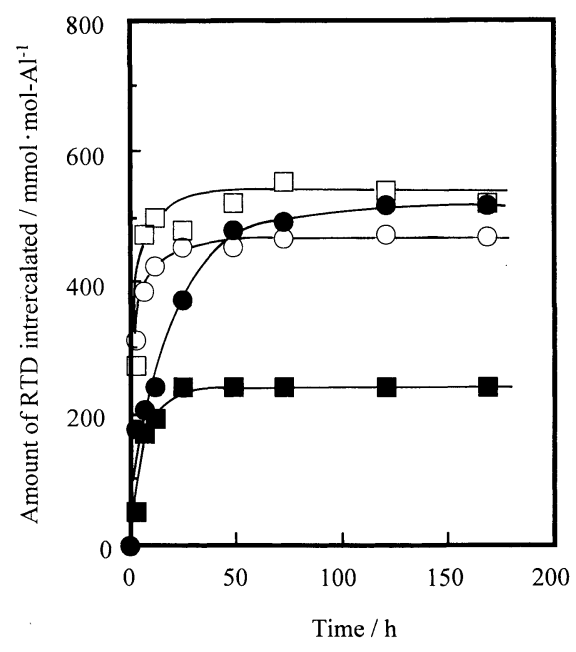

Figure 1 Effect of time on the amount of RTD intercalated into $\mathrm{Mg}-\mathrm{Al}$ oxide by the reconstruction method at $25{ }^{\circ} \mathrm{C}$

$\bigcirc: \operatorname{TTN}(M R=0.24), \square: \operatorname{TTN}(M R=0.33)$

: $\operatorname{DBN}(M R=0.24), \boldsymbol{\square}: \operatorname{DBN}(M R=0.33)$

ン-2,4-ジチオールモノアニオン (DB)を取り込むことを検 討した。

Figure 1 には $\mathrm{Al} /(\mathrm{Mg}+\mathrm{Al})$ モル比 $(M R)$ が異なる $M R=0.24$ と $M R=0.33$ の $\mathrm{Mg}-\mathrm{Al}$ 系 $\mathrm{LDH}$ を用いて, 再構築法 によって LDH層間に取り込まれたTTと DB量を示す. TTの取り込み量はLDHの MRによって異なるが，24 時 間から 48 時間で平衡となった。 $\mathrm{LDH}$ が $M R=0.33$ のとき $\mathrm{TT}$ の取り込み量は $483 \mathrm{mmol} \cdot \mathrm{mol}-\mathrm{Al}^{-1}, M R=0.24$ のとき $434 \mathrm{mmol} \cdot \mathrm{mol}-\mathrm{Al}^{-1}$ となった. $M R$ の違いが TTの取り込 み量に影響した理由は, $\mathrm{LDH}$ の特性として, $\mathrm{Al}^{3+}$ イオン の固溶量の増加とともに基本層と中間層の電荷量が増加 し, 両層間の静電引力が増大するため, $M R=0.24$ の LDH より基本層の正電荷密度の高い $M R=0.33$ の $\mathrm{LDH}$ を用いた 方が，TTの取り込み量が増大したと考えられる。また， $\mathrm{TTN}$ 水溶液中では陰イオン成分としてトリアジントリチ オールモノアニオンと水分子の $\mathrm{OH}^{-}$イオンが共存してい ることによって, LDHの層間へ陰イオンを取り込む際， $\mathrm{TT}$ と $\mathrm{OH}^{-}$イオンの競争反応が生じると考えられる. DB と TTの取り达み量の違いについては, $M R=0.33$ の場合 TTのほうが $\mathrm{DB} よ り$ 取り込み量が多く, $M R=0.24$ の場合 はDBのほうがTTよりわずかに取り込み量が多かった. これは, $M R=0.33$ の LDH では基本層の正電荷密度が高い ため層間が狭く, 分子サイズの小さい TTが取り込まれや すいと考えられる.そして, $M R=0.24$ の場合は基本層の正 電荷密度が低いため, 基本層と陰イオンとの結合力も弱く

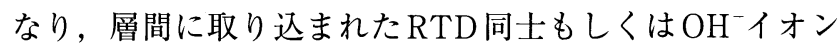
との分子間斥力の違いが取り込み量に影響したと考えられ る. 以降用いた RTD/LDHは $25{ }^{\circ} \mathrm{C} て ゙ 48$ 時間振とうする ことによって合成した。

Figure 2 に炭酸型 $\mathrm{Mg}-\mathrm{Al}$ 系 $\mathrm{LDH}$, 炭酸型 $\mathrm{Mg}-\mathrm{Al}$ 系 $\mathrm{LDH}$ を $500{ }^{\circ} \mathrm{C}$ で 2 時間焼成した熱分解物，そしてTTを取
り込んだ $\mathrm{Mg}-\mathrm{Al}$ 系 $\mathrm{LDH}$ 複合体 ( $\mathrm{T} \mathrm{T} / \mathrm{LDH}$ 複合体) $(M R=0.24)$ と $\mathrm{DB}$ を取り込んだ $\mathrm{Mg}-\mathrm{Al}$ 系 $\mathrm{LDH}$ 複合体 $(\mathrm{DB} / \mathrm{LDH}$ 複合体 $)(M R=0.33)$ のRD 図を示す。炭酸型 $\mathrm{Mg}-\mathrm{Al}$ 系 $\mathrm{LDH}$ の面間隔は $d_{003}=0.78 \mathrm{~nm}$ であり, 原料の炭 酸型 $\mathrm{Mg}-\mathrm{Al}$ 系 $\mathrm{LDH}$ を焼成することによって, XRD スペ クトルはアモルファス状態を示し, 層状構造が破壊されて いることを示している．この焼成した $\mathrm{Mg}-\mathrm{Al}$ 系 $\mathrm{LDH}$ TTNまたは DBN 水溶液で振とうした後, TT/LDH 複合 体の面間隔は $d_{003}=0.83 \mathrm{~nm}, \mathrm{DB} / \mathrm{LDH}$ 複合体の面間隔は $d_{003}=0.80 \mathrm{~nm}$ になったことから, 層状構造が再生され, $\mathrm{RTD}$ が $\mathrm{Mg}-\mathrm{Al}$ 系 $\mathrm{LDH}$ の層間に取り込まれたと考えられ

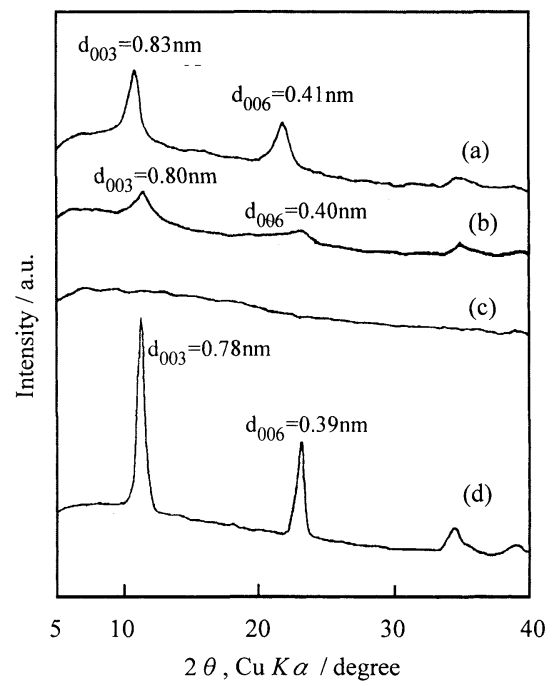

Figure $2 \mathrm{XRD}$ patterns of $\mathrm{LDH}$ and $\mathrm{RTD} / \mathrm{LDH}$ products by the reconstruction method at $25{ }^{\circ} \mathrm{C}$ for $48 \mathrm{~h}$.

(a) TT/LDH $(M R=0.24), \quad$ (b) DB/LDH $(M R=0.33), \quad$ (c) calcined $\mathrm{LDH}$ $\left(\mathrm{Mg}-\mathrm{Al}\right.$ carbonated $\mathrm{LDH}$ was heated at $500{ }^{\circ} \mathrm{C}$ for $2 \mathrm{~h}$. (d) $\mathrm{Mg}-\mathrm{Al}$ carbonated $\mathrm{LDH}(M R=0.24)$

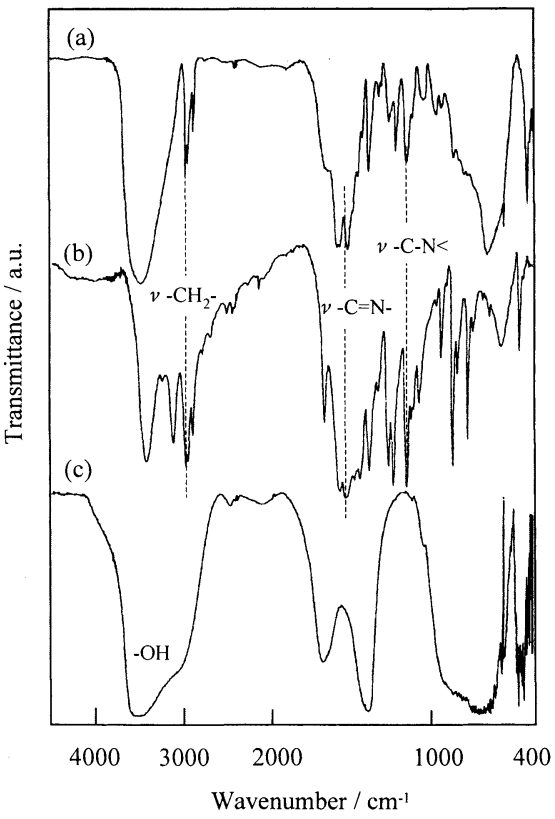

Figure $3 \mathrm{FT}-\mathrm{IR}$ spectra of $\mathrm{LDH}$ and $\mathrm{DB} / \mathrm{LDH}$ product by the reconstruction method at $25{ }^{\circ} \mathrm{C}$ for $48 \mathrm{~h}$.

(a) $\mathrm{DBN}, \quad($ b) $\mathrm{DB} / \mathrm{LDH}(M R=0.24), \quad($ c) $\mathrm{Mg}-\mathrm{Al}$ carbonated $\mathrm{LDH}$ $(M R=0.24)$ 
る.

Figure 3 にDB/LDH 複合体 $(M R=0.24)$ の $\mathrm{FT}-\mathrm{IR}$ スペク トル図を示す． DB/LDH 複合体には DBNに基づく2950 $\mathrm{cm}^{-1}$ 付近にメチレン基- $\mathrm{CH}_{2}$-伸縮振動と $1580 \mathrm{~cm}^{-1}$ 付近卜 リアジン環- $\mathrm{C}=\mathrm{N}-$ 伸縮振動が確認された。ジブチルアミ ノ基 $\mathrm{C}-\mathrm{N}<$ に基づく $1233 \mathrm{~cm}^{-1}$ の吸収が $1210 \mathrm{~cm}^{-1}$ にシフ トしていることから，LDH層間と相互作用していると考 えられる，TT/LDH複合体においてもトリアジン環 $\mathrm{C}=\mathrm{N}$ に基づく伸縮振動が確認された。これらの結果から RTD が $\mathrm{Mg}-\mathrm{Al}$ 系 $\mathrm{LDH}$ の層間に取り込まれたことが明らかとな った。以降用いた $\mathrm{RTD} / \mathrm{LDH}$ 複合体は $M R=0.24$ を使用し た.

次に, RTD/LDH 複合体から塩化物イオンとのイオン交 換法によるRTDの放出を検討した. Figure 4 はDB/LDH

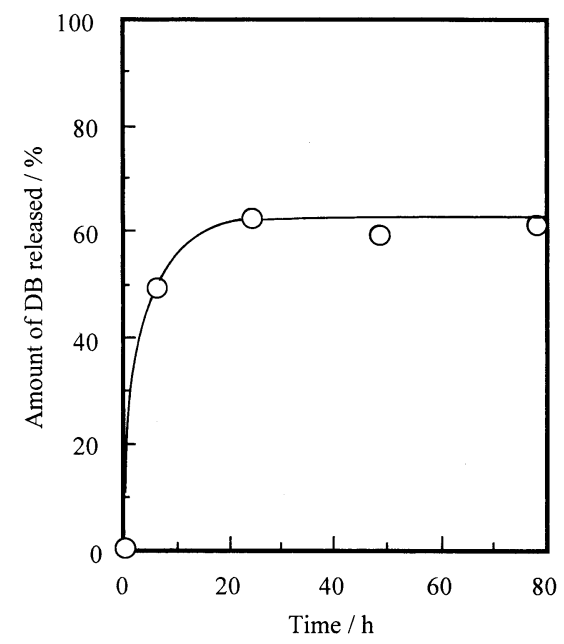

Figure 4 Effect of time on the amount of DB released from $\mathrm{DB} / \mathrm{LDH}(M R=0.24)$ product by the ion exchange method at $25{ }^{\circ} \mathrm{C}$

Initial $\mathrm{NaCl}$ concentration: $100 \mathrm{mmol} / \mathrm{dm}^{3}$ Amount of DB intercalated: $38 \mathrm{mmol} \cdot \mathrm{mol}-\mathrm{Al}^{-1}$

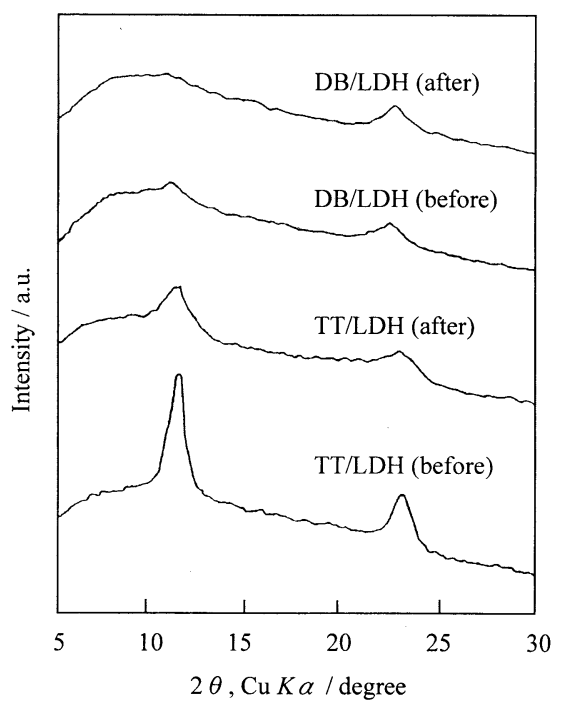

Figure 5 XRD patterns of RTD/LDH $(M R=0.24)$ products obtained before and after ion-exchange with $\mathrm{Cl}^{-}$ion at $25{ }^{\circ} \mathrm{C}$ for $24 \mathrm{~h}$.
複合体の $\mathrm{DB}$ 放出に及ぼす $\mathrm{NaCl}$ 水溶液振とう時間の影響 を示す. Figure 4 から $\mathrm{NaCl}$ 水溶液中で $\mathrm{DB} / \mathrm{LDH}$ 複合体は 振とう時間の増加とともにDBを放出し，24 時間では $\mathrm{DB} / \mathrm{LDH}$ 複合体中の約 $60 \%$ DBが放出され， 72 時間振 とうしてもほとんどDB放出量は変化しなかった。 $\mathrm{DB} / \mathrm{LDH}$ 複合体は，水中では $\mathrm{Cl}^{-}$のアニオン交換反応とと もに $\mathrm{OH}^{-}$イオンのアニオン交換による平衡反応により $\mathrm{DB}$ が100\%は放出されなかったと考えられる. Figure 5に $\mathrm{DB} / \mathrm{LDH}$ 複合体と $\mathrm{TT} / \mathrm{LDH}$ 複合体を $\mathrm{NaCl}$ 水溶液で 24 時 間振とうしたイオン交換前後のXRD図を示す.イオン交 換前後において，ピーク強度は小さくなっているが層状構 造は保持されていた。炭酸型 LDHでは電荷密度の小さい $\mathrm{Cl}^{-}$と $\mathrm{LDH}$ 層間の $\mathrm{CO}_{3}{ }^{2-}$ とのアニオン交換反応が難しいと されている ${ }^{21,22)}$ が, Figure 4 と Figure 5 の結果より, $\mathrm{RTD} / \mathrm{LDH}$ 複合体中の $\mathrm{RTD}$ と $\mathrm{Cl}^{-}$イオンが容易に交換した と考えられる。したがって，RTD/LDH 複合体をハロゲン 化ゴムの架橋剤として利用した場合，RTDはゴムの架橋 凰として作用し, 脱ハロゲンに対してLDHはアクセプタ ーとして作用できると考えられる。

Figure 6には，TT/LDH複合体をDBSによって表面被 覆した DBS/TT/LDH 複合体の FT-IRを示す. DBS 処理 することによって $2950 \mathrm{~cm}^{-1}$ 付近にメチレン基 $\left(-\mathrm{CH}_{2}-\right)$ に 基づく伸縮振動，1400 $1350 \mathrm{~cm}^{-1}$ に $\mathrm{S}=\mathrm{O}$ 伸縮振動, $1040 \mathrm{~cm}^{-1}$ と $1009 \mathrm{~cm}^{-1}$ にベンゼン環に結合するメチレン 基の変角振動が確認された．また，Figure 7 にはDBSま たは DSで处理した TT/LDH 複合体の XRD図を示す。 Figure 7 で示される DBS/TT/LDH複合体または DS/TT/LDH 複合体はFigure 2 に示したAS 処理前の

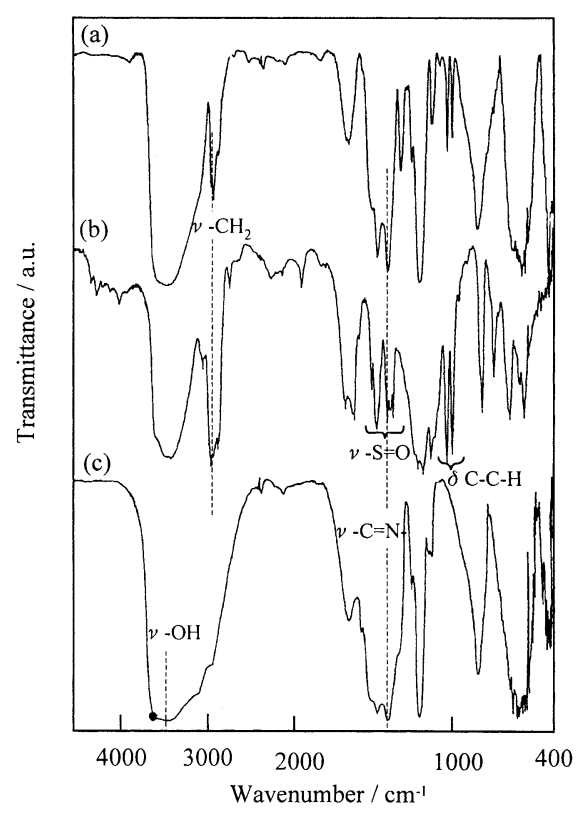

Figure 6 FT-IR spectra of TT/LDH and DBS/TT/LDH products by DBS treatment at $25{ }^{\circ} \mathrm{C}$ for $4 \mathrm{~h}$.

(a) DBS/TT/LDH $(M R=0.24)$, (b) DBS, (c) TT/LDH $(M R=0.24)$ 


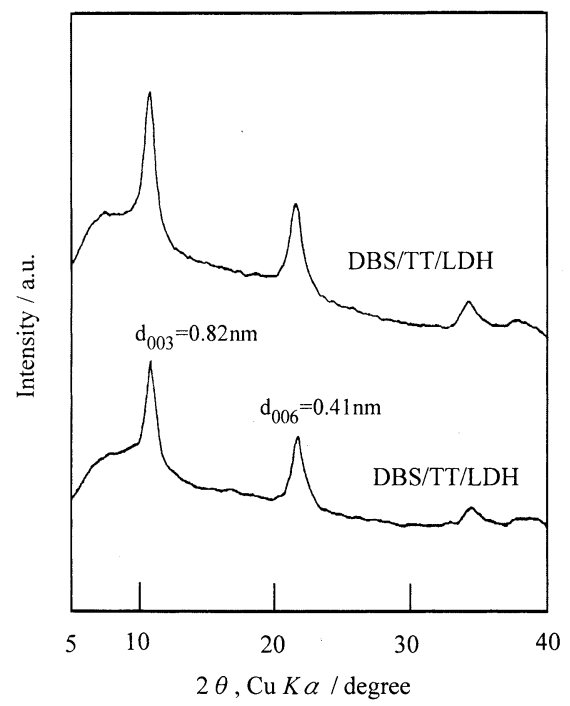

Figure 7 XRD patterns of $\mathrm{AS} / \mathrm{TT} / \mathrm{LDH}(M R=0.24)$ products by DBS or DS treatment at $25{ }^{\circ} \mathrm{C}$ for $4 \mathrm{~h}$.

TT/LDH 複合体と同様の回折ピークが得られた。 そして, Figure 6の FT-IR スペクトル図と Figure 7のXRD図のピ 一ク強度がほとんど変わらない結果から，TT/LDH 複合 体はDBSまたはDSなどの界面活性剂処理による LDH 層 間からのTTの放出掞よび層間での AS とのイオン交換は なく，TT/LDH複合体の表面に ASが吸着した構造を示す と考えられる。

\section{2 架橋特性}

DBS/TT/LDH 複合体を架橋剂として用いて塩素化アク リルゴムの架橋反応を行った。トルク変化はスコーチ性を 示す指標となるものであり，短時間にトルクの増大がある 場合には，架橋の誘導期が短く，作業性そして加工性等が 悪いことを示している.

Figure 8には架橋剤としてTTN，TT/LDH 複合体およ びDBS/TT/LDH 複合体を配合した塩素化アクリルゴムの 架橋曲線を示す. Figure 8の架橋曲線より算出した架橋速 度定数を Table 1 に示す。架橋温度は $170{ }^{\circ} \mathrm{C}$ とした。これ らの結果から，TTN配合系は架橋試験開始後，短時間に トルクが増大し急激な架橋が生じ，いわゆるスコーチが発 生している。一方， DBS/TT/LDH 複合体配合系は $\mathrm{DBS} / \mathrm{TT} / \mathrm{LDH}$ 複合体が $1 \mathrm{phr}$ の場合に架橋が進行しなか ったが，DBS/TT/LDH 複合体配合量の増加とともにトル クが増大し， $6 \mathrm{phr}$ の場合では測定開始 10 分後から架橋 が進み, 架橋時間 40 分で TTN 配合系と同様のトルク值 $0.6 \mathrm{~N} \cdot \mathrm{m}$ を示した. DBS/TT/LDHと TT/LDHを各々 2 phr 配合したときを比較すると，ASで表面処理した DBS/TT/LDHの方が，架橋反応が進行することが明らか となったこれは，ASによってゴムとの相溶性が向上し， 反応が促進されたためと考えられる. Table 1から TTN 配合系では架橋速度定数が 5.12 に対してDBS/TT/LDH 複 合体を $6 \mathrm{phr}$ 配合した系では架橋速度定数が 0.81 となっ

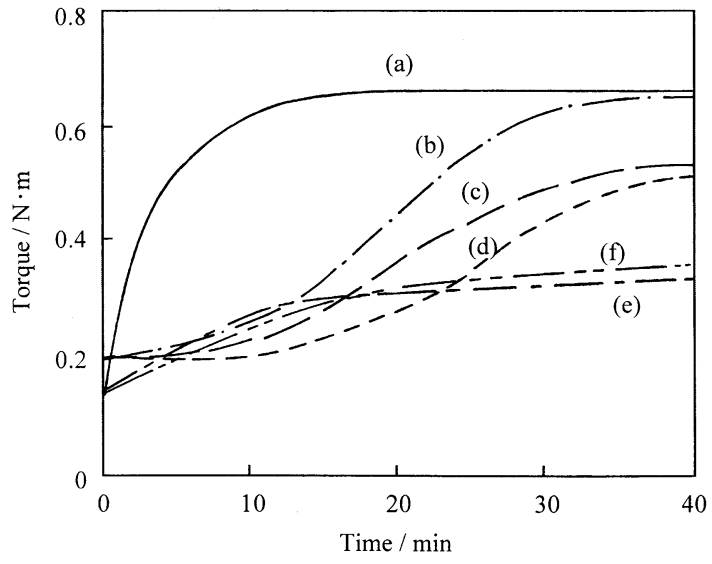

Figure 8 Rheometer curves of ACM curing with DBS/TT/LDH $(M R=0.24)$.

Base formulation (phr); ACM (100), FEF black (60), Stearic acid(1), Antioxidant DP(1), ZnBDC (1)

(a) TTN (0.5), (b) DBS/TT/LDH (6), (c) DBS/TT/LDH (3) (d) DBS/TT/LDH (2), (e) DBS/TT/LDH (1); (f) TT/LDH (2)

Curing temperature: $170{ }^{\circ} \mathrm{C}$

Table 1 Effect of TT-intercalated into $\mathrm{Mg}$-Al oxide $(M R=0.24)$ on curing reaction

\begin{tabular}{lcccccc}
\hline Composition *1/phr & (a) & (b) & (c) & (d) & (e) & (f) \\
\hline TTN & 0.5 & - & - & - & - & - \\
DSB/TT/LDH & - & 6 & 3 & 2 & 1 & - \\
$\mathrm{TT} / \mathrm{LDH}$ & - & \multicolumn{1}{c}{-} & \multicolumn{1}{c}{-} & \multicolumn{1}{c}{-} & \multicolumn{1}{c}{-} & \multicolumn{1}{c}{2} \\
\hline$f_{\max } / \mathrm{N} \cdot \mathrm{m}$ & 0.65 & 0.63 & 0.52 & 0.50 & 0.33 & 0.35 \\
\hline$t_{90} / \mathrm{min}$ & 9.36 & 28.71 & 30.32 & 34.52 & 19.68 & 24.84 \\
$t_{50} / \mathrm{min}$ & 3.23 & 19.35 & 20.32 & 25.48 & 7.10 & 10.06 \\
$t_{10} / \mathrm{min}$ & 0.65 & 8.39 & 10.97 & 13.87 & 0.97 & 0.81 \\
\hline Cure rate constant $/ k$ & 5.12 & 0.81 & 0.73 & 0.23 & 2.01 & 1.73 \\
\hline
\end{tabular}

${ }^{* 1}$ Base formulation (phr); ACM(100), FEF black (60), Stearic acid (1), Antioxidant DP (1), ZnBDC (1)

Curing temperature; $170{ }^{\circ} \mathrm{C}$

た。これは LDH層間に取り込まれたTTが架橋とともに ゴム中に放出され，徐々に架橋反応が進行したために誘導 期を与えたと考えられる.

以上の結果から，DBS/TT/LDH 複合体が塩素化アクリ ルゴムに対して遅延作用のある耐スコーチ性の架橋剂であ ることが明らかとなった。

\section{4. ま と め}

陰イオン交換性の $\mathrm{Mg}-\mathrm{Al}$ 系層状複水酸化物の層間に架 橋剂となるトリアジンジチオール化合物を取り込み，この 複合体の表面を界面活性剤で被覆することによって，トリ アジンジチオール化合物がカプセル化されたと同様の新規 有機/無機ハイブリッド架橋剂を合成することができた. このトリアジンジチオール/無機ハイブリッド複合体を架 橋剤として塩素化アクリルゴムに配合した組成物は，トリ アジンジチオール化合物による急激な架橋反応が生じるこ

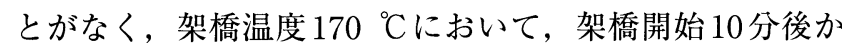
ら反応が進行して, 加工安定性そして耐スコーチ性の架橋 
性組成物となることが明らかとなった。

\section{References}

1) Nakamura, Y., Mori, K., Oka, S.: Nippon Gomu Kyokaishi, 46, 779 (1973)

2 ) Nakamura, Y., Mori, K., Nakamura, T.: Rubber Chem. Technol., 49, 1031 (1976)

3 ) Miyata, S.: Kagaku Gijutsushi MOL, 15(10), 32 (1977)

4 ) Dondi, G., Binda, M. L., Caramella, C., Colombo, P., Conte, U., La Manna, A.: Pharm. Acta. Helv., 58, 259 (1983)

5 ) van der Ven. L., van Gemert, M. L. M., Batenburg, L. F., Keern, J. J., Gielgens, L. H., Koster, T. P. M., Fischer, H. R.: Appl. Clay Sci., 17, 25 (2000)

6 ) Kang, D. H., Desai, K., Lee, J., Hwang, S., Sung, C., Mead, J.: Preprint of the 165th Meeting of the Rubber Division, ACS, Paper No.25 (2004)

7 ) Fuller, R. E., Macturk, K. S.: Kautsch. Gummi Kunstst., 53, 506 (2000)

8 ) Frondel, C.: Am. Mineral., 26, 295 (1941)

9) Miyata, S.: Clays Clay Miner., 28, 50 (1980)

10) Miyata, S.: Zeolite, 8, 7 (1991)

11) Ulibarri, M. A., Pavlovic, I., Barriga, C., Hermosin, M. C., Cornejo, J.: Appl. Clay Sci., 18, 17 (2001)

12) You, Y., Vance, G. F., Zhao, H.: Colloids Surf. A, 205, 161 (2002)
13) Park, M., Lee, E. J., Choy, J. H., Lee, C. I., Kim, J. E., Choi, J.: J. Phys. Chem. Solids, 65, 513 (2004)

14) He, Q. L., Yin, S., Sato, T.: Trans. Mater. Res. Soc. Jpn., 28, 301 (2003)

15) Aisawa, S., Narita, E.: Zeolite, 17, 101 (2000)

16) Aisawa, S., Hirahara, H., Narita, E.: Trans. Mater. Res. Soc. Jpn., 10, 260 (2003)

17) Aisawa, S., Hirahara, H., Takahashi, S., Umetsu, Y., Narita, E.: Chem. Lett., 33, 306 (2004)

18) Baoguang, L., Yuan, H., Rui, Z., Zuyao, C., Weicheng, F.: Mater. Res. Bull., 38, 1567 (2003)

19) Liao, C. S., Ye, W. B.: Electrochim. Acta., 49, 4993 (2004)

20) Wang, G., Cai, F., Si, L., Duan, X., Wang, Z.: Chem. Lett., 34, 94 (2005)

21) Miyata, S.: Clays Clay Miner., 31, 305 (1985)

22) Kameda, T., Yoshioka, T., Hoshi, T., Uchida, M., Okuwaki, A.: Separ. Sci. Technol., 42, 25 (2005)

\section{日本語表記参考文献}

1) 中村儀郎, 森 邦夫, 岡 作二郎：日本ゴム協会誌, 46, 779 (1973)

3 ）宮田茂男：科学技術誌 MOL, 15(10)，32 (1977)

10）宮田茂男：ゼオライト，8，7(1991)

15）會澤純雄，成田栄一：ゼオライト，17，101（2000）

\section{本会発行出版物ご案内}

\section{ゴ4用語 辞典 B 6 版 400 頁 (1997.10発行) \\ 定 価 会員価格 送料 4,252 円 (税込) 450円}

* お申込の場合は, 必要事項(送付先住所, 勤務先, 氏名, 電話番号など)をご記入のうえ, FAXして下さい. 